\title{
The ecological state of the raw material zone of the enterprises supplying beef for baby food
}

\author{
Nikolay Zabashta ${ }^{1,}{ }^{*}$, Elena Golovko ${ }^{1}$, Irina Sinelshchikova ${ }^{1}$, and Anastasia Androsova \\ ${ }^{1}$ Department of Toxicology and Feed Quality, Federal State Budgetary Scientific Institution \\ Krasnodar Research Centre for Animal Husbandry and Veterinary Medicine, 4, Pervomayskaya \\ Street, 350055, Krasnodar, Russian Federation
}

\begin{abstract}
Subjects of the research: soils, pasture and cultivated plants, vegetable raw materials, prepared feed of the raw material zone of the Branch of the Tikhoretsky Children's Meat Canning Plant of DANONRUSSIA JSC. The quantitative content of mobile forms of heavy metals in soils under the main feed crops and their accumulation in finished feeds was determined. The a soil with a high humus content cover in the area of the surveyed farms is mainly represented by carbonate weakly humus heavy-duty "chernozem", which occupies $82.5 \%$ of all land. Fodder raw materials in the autumn-winter season 2019-2020 is safe in quantitative content regulated by standards of elements of heavy metals. Their contents were established: mercury $\leq 0.01 \mathrm{mg} / \mathrm{kg}$, cadmium $\leq 0.2 \mathrm{mg} / \mathrm{kg}$, lead $\leq$ $2.0 \mathrm{mg} / \mathrm{kg}$ and arsenic $\leq 0.5 \mathrm{mg} / \mathrm{kg}$. However, there was an insignificant $(1-2 \%)$ increase in the zinc content in the silage from the green mass of corn and haylage from the green mass of alfalfa. It was established that the remains of the prohibited pesticides are in trace amounts or practically absent in the feed of the raw material zone. The monitoring results will be used in farms - suppliers of beef for the production of baby food - canned meat and meat and vegetable.
\end{abstract}

\section{Introduction}

Beef remains the basis for the production of baby food, especially since the growth of pork production in the southern regions of Russia in an unstable epidemiological situation is difficult to guarantee [1].

The requirements for raw materials for baby food are much higher than those for ordinary purposes, and therefore, it is especially important to obtain environmentally friendly high-quality beef [2]. Currently, a new approach is needed to develop environmentally friendly technologies for the production of vegetable feed for livestock fed in the raw material zone of the Tikhoretsky plant for canned meat for baby food (Branch of DANON RUSSIA JSC) [3-4].

The environmental safety of feeds during fattening of bull calves for the production of baby food has a fundamental role, since a fairly wide range of hazardous substances of

\footnotetext{
* Corresponding author: n.zabashta@bk.ru
} 
chemical, biological and physical nature get from the soil into feed and then into meat raw materials [5-6].

Based on many years of monitoring in the raw material zone regarding toxicants, in 2020, the Krasnodar Scientific Centre for Animal Husbandry and Veterinary Medicine developed recommendations for ensuring environmental safety in the raw material zone for the production of beef for baby food, which were based on real research. Their relevance lies in the practical need to ensure the uninterrupted operation of suppliers of environmentally friendly meat raw materials for the production of baby food. Safety should be ensured along the entire chain of the production cycle, from the selection of a specialized environmentally friendly raw material zone to obtain vegetable feed raw materials to the production of safe high-quality meat [7-10].

The aim of the research is to monitor the environmental status of soils and feed in the raw material zone of beef suppliers for baby food in the autumn - winter season of 20192020 .

To date, the status of an environmentally friendly raw material zone and environmentally friendly agricultural products has not been determined.

The exclusive experience of the Tikhoretsky Children's Canned Meat Plant, branch of DANON-RUSSIA JSC in the Tikhoretsky District of the Krasnodar Territory shows the inability to use ordinary meat due to exceeding the acceptable levels of toxic substances in it. There was a need to search for a specialized raw material zone.

In the process of maintaining the environmental safety of the operated raw material zone in southern Russia, annual monitoring of the environmental conditions of soils, drinking water and feed for young cattle fed for the purpose of providing the beef with the baby food industry is relevant.

\section{Materials and methods}

This paper presents the results of a study of the environmental situation in the enterprises of Bratkovskiy of the Korenovsky District, Khutorok of Novokubansky District, Krasnodar Territory; Agrofirm "Uralan" of the Republic of Kalmykia, suitable for rearing bulls for baby food. Monitoring was carried out in accordance with regulatory documents.

The object of the study is the raw material zone for the production of beef for baby food. Subjects of the research: soils, pasture and cultivated plants, vegetable raw materials, prepared feed of the raw material zone of the Branch of the Tikhoretsky Children's Meat Canning Plant of DANON-RUSSIA JSC. Monitoring was carried out in three farms of the raw material zone (Krasnodar Territory and the Republic of Kalmykia). In these farms, the content of mobile forms of toxic elements in the arable layer of the soil was established, the levels of accumulation of toxic substances in plants, prepared feeds and feed products were determined. The selection of soil samples was carried out in accordance with the requirements of interstate standards (interstate standard) (State Standard 17.4.4.02-84, State Standard 28168-89; State Standard 2761-84). The content of toxic elements was determined according to State Standard 26931-86, State Standard 30178-96, State Standard 26934-86, State Standard 26930-86, Guidelines 5178-90; residual amounts of banned pesticides according to accepted guidelines [11].

The quantitative content of mobile forms of heavy metals in soils under the main feed crops and their accumulation in finished feeds was determined. The studies were complicated by the fact that the maximum permissible concentrations of metals for various types of soils have not yet been established.

Therefore, we used the recommended approximate permissible concentrations of toxic substances in the soil (APC) in the arable horizon of the soil from 0 to $300 \mathrm{~mm}$. 


\section{Results and discussion}

The status of the specialized raw material zone was determined after an agrochemical examination of soils, drinking water and feed.

Based on the analysis of the available monitoring data, every 3 months (according to the seasons of the year), proposals were made to include specific farms that passed environmental control in the raw material zone. As of January 2020, the list of suppliers was updated and amounted to 27 households.

List of farms-suppliers of beef to the Branch" Plant of children's meat canned food «Tikhoretsky JSC DANON RUSSIA, for the period from January to March 2020 are presented in Table 1.

Table 1. List of farms-suppliers of beef to the Branch" Plant of children's meat canned food «Tikhoretsky JSC DANON RUSSIA, for the period from January to March 2020.

\begin{tabular}{|c|c|c|}
\hline № & $\begin{array}{l}\text { The name of the supplying enterprise in the raw material zone of the } \\
\text { Tikhoretsky canned children's meat plant }\end{array}$ & Location (district) \\
\hline \multicolumn{3}{|c|}{ Krasnodar Territory } \\
\hline 1 & Novyy put & Bryukhovetskiy \\
\hline 2 & Russ & Timashevskiy \\
\hline 3 & Rassvet & Pavlovskiy \\
\hline 4 & Oktyabr & Kalininskiy \\
\hline 5 & Bratkovskiy & Korenovskiy \\
\hline 6 & CJSC named after T.G. Shevchenko & Tbilisskiy \\
\hline 7 & Druzhba JSC & \multirow{2}{*}{ Kanevskoy } \\
\hline 8 & Breeding Plant "Volya" JSC & \\
\hline 9 & Lenin Collective farm & \multirow{2}{*}{ Novokubanskiy } \\
\hline 10 & Khutorok CJSC & \\
\hline 11 & Znamya Lenina & \multirow{2}{*}{ Shcherbinovskiy } \\
\hline 12 & Agrofirma «Novoshcherbinovskaya» & \\
\hline \multicolumn{3}{|c|}{ Stavropol Territory } \\
\hline 13 & Lesnaya Dacha & Ipatovskiy \\
\hline 14 & Kolkhoz Rodina & Krasnogvardeyskiy \\
\hline 15 & Stavropol-Kavkazskiy & Petrovskiy \\
\hline \multicolumn{3}{|c|}{ Republic of Kalmykia } \\
\hline 16 & Agrofirma «Uralan» & Priyutnenskiy \\
\hline \multicolumn{3}{|c|}{ Rostov region } \\
\hline 17 & Yuzhnoye JSC & \multirow{2}{*}{ Salskiy } \\
\hline 18 & Stefanov V.P. farm & \\
\hline 19 & Pavlishin Anatoliy Georgiyevich farm & \multirow{4}{*}{ Peschanokopskiy } \\
\hline 20 & Agropark-Razvilnoye & \\
\hline 21 & Gabelaya Elgudzhi Mikhaylovich farm & \\
\hline 22 & Tulskiy A.V. farm & \\
\hline 23 & Nikiforovskiy M.I. farm & Proletarskiy \\
\hline \multicolumn{3}{|c|}{ Voronezh region } \\
\hline 24 & Buturlinovskiy Agrocomplex LLC & Buturlinovskiy \\
\hline 25 & Liskinskiy & Liskinskiy \\
\hline 26 & Novomarkovskoye LLC & \multirow{2}{*}{ Kantemirovskiy } \\
\hline 27 & NIVA LLC & \\
\hline
\end{tabular}

Three farms are excluded from the raw material zone after revealing some facts of the presence in the soil and feed of residual amounts of toxic substances close to acceptable.

The order and frequency of control of drinking water, soil and feed of our own production according to safety indicators was carried out in accordance with the "Scheme 
of monitoring the farm - a supplier of productive animals for processing into meat raw materials for the production of baby food", developed jointly with processors of meat raw materials.

Monitoring was carried out in the autumn of 2019 and in the winter of 2020 for each beef supplying farm.

During the study period no excess of the maximum permissible residual amounts of toxic substances in drinking water for livestock was recorded in the farms of the raw material zone.

Analysis of water samples for the content of heavy metals showed that the excess of maximum permissible concentrations was not detected for regulated toxicants.

Prohibited pesticides in water are not found. Studies of the chemical composition of drinking water samples for animals in the raw material zone established their safety and compliance with interstate standards (Table 2).

Table 2. The content of chemical elements in the drinking water of the raw material zone of the Tikhoretsky Children's Canned Meat Plant Branch of DANON RUSSIA JSC in 2019-2020, mg / kg.

\begin{tabular}{|l|l|c|c|}
\hline \multicolumn{1}{|c|}{ Test standard } & \multicolumn{1}{c|}{ Item } & $\begin{array}{c}\text { The permissible } \\
\text { level }\end{array}$ & Test result \\
\hline \multicolumn{3}{|c|}{ Toxic elements } \\
\hline State Standard 30692-2000 & Lead & 0.03 & $<0.001$ \\
\hline State Standard 26930-86 & Arsenic & 0.05 & $<0.0025^{\text {a }}$ \\
\hline State Standard 30692-2000 & Cadmium & 0.001 & $<0.001$ \\
\hline Methodical Instructions 5178-90 & Mercury & 0.0005 & $<0.0005^{\text {a }}$ \\
\hline
\end{tabular}

Note: a - lowest limit detection by the method

Agricultural agrolandscapes, cultural and natural pasture lands are located in the zone of temperate continental climate.

The a soil with a high humus content cover in the area of the surveyed farms is mainly represented by carbonate weakly humus heavy-duty "chernozem", which occupies $82.5 \%$ of all land.

In the agrarian zone, the level of soil acidity ranges from neutral $(\mathrm{pH} \mathrm{7.0)}$ to alkaline (pH 8.6).

The high content of metabolic potassium $(32.0 \mathrm{mg} / 100 \mathrm{~g})$ is explained by the introduction of potassium in the composition of fertilizers to ensure sowing of crops. On pasture lands, a low indicator of exchange potassium (16.0 mg / $100 \mathrm{~g})$ was noted. When assessing soil contamination with residual amounts of toxic elements, we used the estimated allowable amounts taking into account Clarks of the raw material zone (Table 3).

Table 3. Approximate permissible concentrations (APC) of toxic elements in soils, $\mathrm{mg} / \mathrm{kg}$.

\begin{tabular}{|l|c|}
\hline \multicolumn{1}{|c|}{ Item } & $\begin{array}{c}\text { Approximate permissible concentrations (APC) of toxic } \\
\text { substances in the soil, including clarks) * }\end{array}$ \\
\hline Zinc (gross forms) & 100.0 \\
\hline Copper (gross forms) & 55.0 \\
\hline Lead (mobile forms) & 32.0 \\
\hline Zinc (mobile forms) & 23.0 \\
\hline Copper (mobile forms) & 3.0 \\
\hline Mercury (mobile forms) & 2.1 \\
\hline Arsenic (mobile forms) & 2.0 \\
\hline Cadmium (mobile forms) & 2.0 \\
\hline
\end{tabular}

Note: ${ }^{*}$ - Clarks in the chernozems of the raw material zone $(\mathrm{mg} / \mathrm{kg}): \mathrm{As}-0.1 ; \mathrm{Cd}-0.3 ; \mathrm{Cu}$ - 18.0; $\mathrm{Pb}-18.0 ; \mathrm{Zn}-37.0$

The total zinc content in the amount of up to $70.0 \mathrm{mg} / \mathrm{kg}$ in the examined soils did not exceed (APC); in the soils of crop rotation it was higher (up to $85.0 \mathrm{mg} / \mathrm{kg}$ ), which is obviously the result of its application with pesticides containing zinc. However, zinc is 
currently not regulated by regulations. The total lead content in corn is $12.0 \pm 2.2 \mathrm{mg} / \mathrm{kg}$. The content of the gross form of cadmium under corn is $0.10 \pm 1.5 \mathrm{mg} / \mathrm{kg}$. In the Korenovsk region, the content of gross and mobile forms of heavy metals in soils under the main crops, alfalfa and maize does not exceed permissible levels (Table 4).

Table 4. The quantitative composition of toxic elements in the soils of OJSC "Bratkovsky" of Korenovsky district, $\mathrm{mg} / \mathrm{kg}$.

\begin{tabular}{|c|c|c|c|c|}
\hline \multirow{3}{*}{ Toxicant } & \multicolumn{3}{|c|}{ Soil } \\
\cline { 2 - 5 } & \multicolumn{2}{|c|}{ Under corn } & \multicolumn{2}{c|}{ Under alfalfa } \\
\cline { 2 - 5 } & total forms & mobile forms & $<$ total forms & $<0.005$ \\
\hline $\mathrm{Hg}$ & $<0.005$ & $<0.005$ & $\leq 0.06$ & 0.02 \\
\hline $\mathrm{Cd}$ & $0.09-0.25$ & $\leq 0.06$ & $\leq 8.43$ & 0.46 \\
\hline $\mathrm{Pb}$ & $9.80-14.2$ & $\leq 1.07$ & $<0.002$ & $<0.002$ \\
\hline $\mathrm{As}$ & $<0.002$ & $<0.002$ & & \\
\hline
\end{tabular}

Mercury and arsenic were contained in insignificant amounts, below the sensitivity values of the determination method.

The content of total and mobile cadmium was 0.5-10 times lower than permissible. The content of gross and mobile lead is 4-60 times lower than permissible.

The content of total and mobile forms of heavy metals in the soils of the Novokubansky district of the Krasnodar Territory under the main crops did not exceed permissible levels (Table 5).

Table 5. The quantitative composition of toxic elements in the soils of CJSC "Khutorok", $\mathrm{mg} / \mathrm{kg}$.

\begin{tabular}{|c|c|c|c|c|}
\hline \multirow{3}{*}{ Toxicant } & \multicolumn{3}{|c|}{ Soil } \\
\cline { 2 - 5 } & \multicolumn{2}{|c|}{ Under corn } & Under alfalfa \\
\cline { 2 - 5 } & gross forms & mobile forms & gross forms & mobile forms \\
\hline $\mathrm{Hg}$ & $<0.005$ & $<0.005$ & $<0.005$ & $<0.005$ \\
\hline $\mathrm{Cd}$ & 0.30 & 0.12 & 0.30 & 0.10 \\
\hline $\mathrm{Pb}$ & 12.25 & 2.50 & 12.30 & 2.65 \\
\hline $\mathrm{As}$ & $<0.002$ & $<0.002$ & $<0.002$ & $<0.002$ \\
\hline
\end{tabular}

Mercury and arsenic were contained in insignificant amounts - below the determination values.

The content of total and mobile forms of heavy metals in the soils of Uralan Agrofirm in the Priyutnensky district of the Republic of Kalmykia under pasture grasses and main crops did not exceed permissible levels (Table 6).

Table 6. The quantitative composition of toxic elements in the soils of the Uralan Agrofirm,

Priyutnensky district of the Republic of Kalmykia, mg / kg.

\begin{tabular}{|c|c|c|c|c|c|c|c|}
\hline \multirow{2}{*}{} & \multicolumn{6}{|c|}{ Soil } \\
\cline { 3 - 8 } Toxicant & \multicolumn{2}{|c|}{ under pasture grasses } & \multicolumn{2}{c|}{ under Sudan grass } & \multicolumn{2}{c|}{ under barley } \\
\cline { 3 - 8 } & total forms & $\begin{array}{c}\text { mobile } \\
\text { forms }\end{array}$ & $\begin{array}{c}\text { total } \\
\text { forms }\end{array}$ & $\begin{array}{c}\text { mobile } \\
\text { forms }\end{array}$ & $\begin{array}{c}\text { total } \\
\text { forms }\end{array}$ & $\begin{array}{c}\text { mobile } \\
\text { forms }\end{array}$ \\
\hline $\mathrm{Hg}$ & $\mathrm{Hg}$ & $<0.005$ & $<0.005$ & $<0.005$ & $<0.005$ & $<0.005$ & $<0.005$ \\
\hline $\mathrm{Cd}$ & $\mathrm{Cd}$ & 0.15 & 0.07 & 0.02 & 0.12 & 0.15 & 0.09 \\
\hline $\mathrm{Pb}$ & $\mathrm{Pb}$ & 9.20 & 0.96 & 12.00 & 1.25 & 8.05 & 0.50 \\
\hline $\mathrm{As}$ & $\mathrm{As}$ & $<0.002$ & $<0.002$ & $<0.002$ & $<0.002$ & $<0.002$ & $<0.002$ \\
\hline
\end{tabular}


Mercury and arsenic were contained in insignificant amounts - below the limit of determination of the method, respectively, $<0.005$ and $<0.002 \mathrm{mg} / \mathrm{kg}$. The content of the total and mobile cadmium is 10 times lower (APC).

The content of the total and mobile lead is lower (APC) 3-30 times.

As a result of studies on the content of pesticides, it was found that residual amounts of hexachlorocyclohexane isomers, as well as dichlorodiphenyl trichloromethylmethane metabolites, were present in almost every soil sample in insignificant amounts.

The residual amounts of toxicants did not exceed $0.2 \mathrm{mg} / \mathrm{kg}$, which was significantly lower than the maximum permissible concentrations.

The results of the study of pasture fodder plants, feed for the content of residual amounts of pesticides, heavy metals, nitrates and nitrites showed that they met the safety requirements for toxic substances (tab. 7-9).

Table 7. Safety indicators for livestock feed in CJSC Khutorok of Novokubanskiy district.

\begin{tabular}{|c|c|c|c|c|c|c|c|c|}
\hline \multirow{2}{*}{\multicolumn{2}{|c|}{ Item }} & \multicolumn{7}{|c|}{ The number of toxicants in natural feed, $\mathrm{mg} / \mathrm{kg}$} \\
\hline & & \multirow{2}{*}{$\begin{array}{c}\begin{array}{c}\text { compound } \\
\text { feed }\end{array} \\
<0.005 \\
\end{array}$} & \multirow{2}{*}{$\begin{array}{c}\begin{array}{c}\text { herbs, green } \\
\text { mass }\end{array} \\
<0.005 \\
\end{array}$} & \multirow{2}{*}{$\begin{array}{c}\begin{array}{c}\text { corn, } \\
\text { green mass }\end{array} \\
<0.005 \\
\end{array}$} & \multirow{2}{*}{$\begin{array}{c}\begin{array}{c}\text { alfalfa, } \\
\text { green mass }\end{array} \\
<0.005\end{array}$} & \multirow{2}{*}{$\begin{array}{c}\text { salt } \\
<0.005 \\
\end{array}$} & \multirow{2}{*}{$\begin{array}{c}\text { chalk } \\
<0.005 \\
\end{array}$} & \multirow{2}{*}{$\begin{array}{c}\text { water } \\
<0.005\end{array}$} \\
\hline Heavy & $\mathrm{Hg}$ & & & & & & & \\
\hline metals & $\mathrm{Cd}$ & 0.03 & 0.03 & 0.03 & 0.03 & 0.001 & 0.002 & $<0.01$ \\
\hline & $\mathrm{Pb}$ & 0.21 & 0.14 & 0.31 & 0.63 & 0.061 & 0.004 & 0.002 \\
\hline & As & $<0.0025$ & $<0.0025$ & $<0.0025$ & $<0.0025$ & $<0.0025$ & $<0.0025$ & $<0.0025$ \\
\hline \multicolumn{2}{|l|}{ Nitrates } & 27.0 & 34.0 & 32.0 & 39.0 & 0.0 & 0.0 & 0.0 \\
\hline \multicolumn{9}{|c|}{$\begin{array}{lc}\text { Nitrites } & 0.0 \\
\end{array}$} \\
\hline \multicolumn{5}{|c|}{ Hexachlorocyclohexane $(\alpha, \beta, \gamma-$ isomers $)$} & $<0.004$ & & & \\
\hline \multicolumn{5}{|c|}{ Dichlorodiphenyl trichloromethylmethane } & $<0.005$ & & & \\
\hline \multicolumn{9}{|c|}{$\begin{array}{l}\text { Heptachlor, malathion, metaphos, bazudine, } \\
\text { phosphamide, dimethylamine salt }\end{array}$} \\
\hline
\end{tabular}

Table 8. Safety indicators for livestock feed in the Uralan Agrofirm, Republic of Kalmykia.

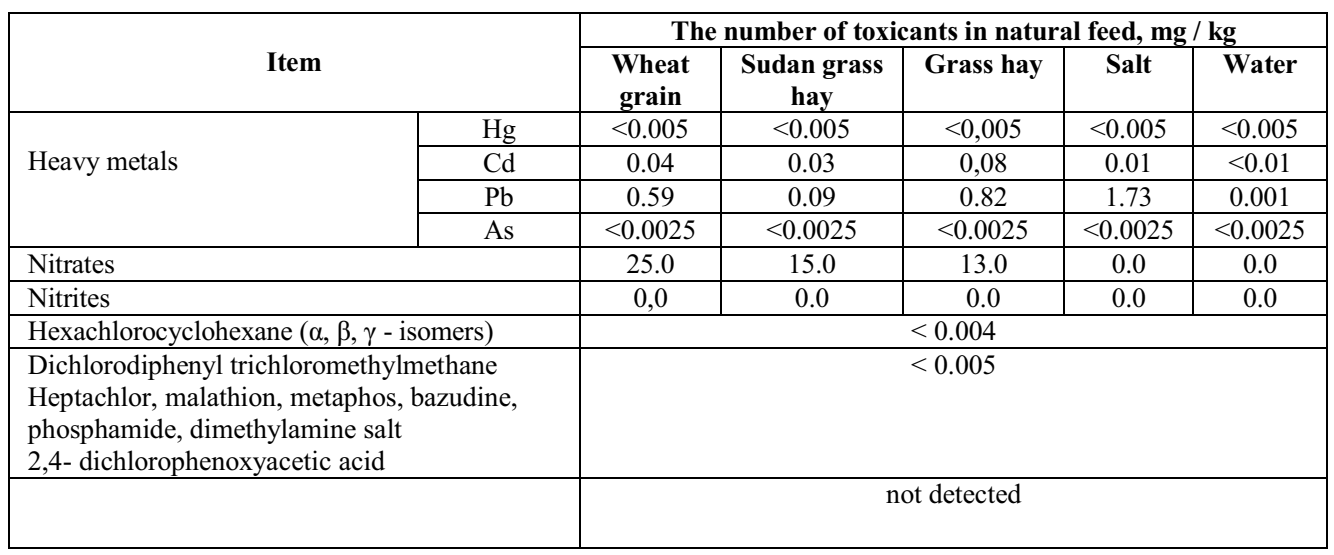

Table 9. Indicators of safety for feeding stuffs for livestock in the Bratkovskiy farm of Korenovskiy district, $\mathrm{mg} / \mathrm{kg}$.

\begin{tabular}{|c|c|c|c|}
\hline \multirow{2}{*}{\multicolumn{2}{|c|}{ Item }} & \multicolumn{2}{|c|}{$\begin{array}{l}\text { The number of toxicants in natural feed, } \\
\mathrm{mg} / \mathrm{kg}\end{array}$} \\
\hline & & miscellaneous grasses & alfalfa \\
\hline \multirow{4}{*}{ Heavy metals } & $\mathrm{Hg}$ & $<0.005$ & $<0.005$ \\
\hline & $\mathrm{Cd}$ & 0.04 & 0.03 \\
\hline & $\mathrm{Pb}$ & 0.59 & 0.09 \\
\hline & As & $<0.0025$ & $<0.0025$ \\
\hline
\end{tabular}




\begin{tabular}{|l|c|c|}
\hline Nitrates & 25,0 & 15.0 \\
\hline Nitrites & 0,0 & 0.0 \\
\hline Hexachlorocyclohexane $(\alpha, \beta, \gamma$ - isomers) & $<0.004$ & $<0.004$ \\
\hline Dichlorodiphenyl trichloromethylmethane & $<0.005$ & not detected \\
\hline $\begin{array}{l}\text { Heptachlor, karbofos, metaphos, bazudine, } \\
\text { phosphamide, 2,4-dichlorophenoxyacetic acid } \\
\text { dimethylamine salt, Danadim, Fastac, Alto, Citcor, } \\
\begin{array}{l}\text { Benlat, Rex, Tilt, Desormone, Cowboy } \\
\hline\end{array}\end{array}$ & & $<0.005$ \\
\hline
\end{tabular}

In comparison with the data of other authors [11-15], our results indicate the safety of the raw material zone. In order to reduce the accumulation of residual amounts of pesticides and mycotoxins in fodder plants, it is recommended to take into account varietal characteristics of cultivated crops, the structure of sown areas, crop rotation, the main processing system; widely use biological means of protecting crops from pests, biologically active substances (immunostimulants, immunoinductors); reduce the number of chemical treatments of crops against weeds, pests, diseases; apply detoxicants on Fusarium-affected grain; when harvesting silage and haylage, use biological preservatives based on probiotics and prebiotics. Suppliers were advised to limit the use of fungicides containing zinc.

\section{Conclusion}

Research work was carried out as part of the ecologization of the food market for children and functional nutrition.

The raw material zone of the autumn-winter season 2019-2020 was updated based on the data of environmental monitoring of the safety of soils, drinking water, feed raw materials.

Fodder raw materials in the autumn-winter season 2019-2020 is safe in quantitative content regulated by standards of elements of heavy metals. Their contents were established: mercury $\leq 0.01 \mathrm{mg} / \mathrm{kg}$, cadmium $\leq 0.2 \mathrm{mg} / \mathrm{kg}$, lead $\leq 2.0 \mathrm{mg} / \mathrm{kg}$ and arsenic $\leq 0.5 \mathrm{mg} / \mathrm{kg}$. The content of residual amounts of zinc does not exceed the maximum permissible level. However, there was an insignificant (1-2\%) increase in the zinc content in the silage from the green mass of corn and haylage from the green mass of alfalfa.

It was established that the remains of the prohibited pesticides (Hexachlorocyclohexane$\alpha, \beta, \gamma$-isomers, trichloromethyldi (p-chlorophenyl) methane and its metabolites, heptachlor) are in trace amounts or practically absent in the feed of the raw material zone. No residual amounts of such insecticides as Danadim, Citcor, Fastak were found on the crops; fungicides - Alto, Benlat, Rex, Tilt; herbicides - Desormon, Cowboy.

The monitoring results will be used in farms - suppliers of beef for the production of baby food - canned meat and meat and vegetable.

\section{References}

1. L. Bartoň, D. Bureš, V. Kudrna, American Journal of Food Science and Technology, 2(6), 192-195 (2014) Doi: 10.12691/ajfst-2-6-4

2. K. Krastev, Biotechnology in Animal Husbandry, 31(1), 1-12 (2015)

3. K. Balakrishna, S. N Nethravathi, K. Harshitha, Maharaja, International Journal of Engineering Science and Computing, 6(5), 5326-5330 (2016) http://ijesc.org/ DOI 10.4010/2016.1304 
4. S. Vinayak, S. D. Apte, International Journal of Advanced Research in Computer Science and Software Engineering, 3(9) (2013)

5. A. Egeru, O. Wasonga, G. Gabiri , L. MacOpiyo, J. Mburu, J. Gilbert, M. M. Hindawi, Applied and Environmental Soil Science, $15 \quad$ (2019) https://Doi.org/10.1155/2019/6874268

6. L. Pociene, L. Sarunaite, V. Tilvikiene, J. Slepetys, and Z. Kadziuliene, Biologija, 59(2), 195-200 (2013)

7. L. Song, X. Bao, X. Liu, F., Journal of Arid Land, 4(1), 3-10 (2012)

8. J. Poore, T. Nemecek, Science Advances, 360(6392), 987-992 (2018) DOI: 10.1126/ Science. Aaq 0216

9. K. R. Mbatha, D. Ward, Journal of Arid Environments, 74(10), 1294-1301 (2010)

10. A. Fatubarin, M. R. Olojugba, Journal of Ecology and the Natural Environment, 6(4), 182-189 (2014)

11. L. Zhang, J. Gala, G. Minoldo, Applied and Environmental Soil Science, Article ID 532807, 6 (2013)

12. J. Rodriguez, J. Unruh, M. Villarreal-Castro, O. Murillo, Meat Science, 96(3), 13401344 (2013) DOI: 10.1016/j.meatsci.2013.10.024

13. E. Garcia, P. Siles, L. Eash, R. V. Der Hoek, Cambridge University Press, 55(5), 776$792(2018)$

14. L. N. Semenova, Y. M Semenov, Geography and natural resources, 31(2), 116-123 2010 DOI: 10.1016/j.gnr.2010.06.005

15. Y. Li , Z. Wang , F. Qin, Z. Fang, X. Li, G. Li, Journal of Chemistry (2018) Articlehttps://doi.org/10.1155/2018/2198176 